\title{
Gametogenic cycle of Crassostrea gigas in contrasting Mediterranean habitats: marine (Gulf of Tunis) and continental (Bizert lagoon) culture sites
}

\author{
Salwa Dridi ${ }^{1^{*}}$, Mohamed Salah Romdhane ${ }^{2}$ and M'hamed Elcafsi ${ }^{3}$
}

\begin{abstract}
Background: The gametogenic cycle of Crassostrea gigas, a species imported into the Mediterranean for aquaculture, has been studied (May 2005 to July 2006) in two contrasting habitats of Tunisia: the Bizert lagoon, where oyster farms have been developed since 1970, and the Gulf of Tunis, where oysters have been experimentally farmed during this study, to assess the potential of this latter marine area for sustaining oyster-culture.

Results: The sexual cycle of the species was described through the histological examination of the gonads, the estimation of oocytes diameter, and the assessment of its condition and gonadal condition indices. The applied techniques gave similar results. The gametogenic cycle of $C$. gigas was precocious and more intense in oysters farmed within the lagoon than in the marine area, considering as well gonadal growth, maturation stages and gametes release.

Conclusions: The obtained results are probably related with the different environmental conditions of the studied habitats, temperature and food supply, in particular. The sexual cycle of the species was successfully completed in the marine area, stressing the invasive character of C. gigas.
\end{abstract}

Keywords: Oysters, Gametogenesis, Chlorophyll a, Farming

\section{Background}

Oyster culture is a rather recent activity in Tunisia developed in the beginning of the previous century, where a breeding attempt of the species Crassostrea angulata in the lagoon of Ghar El Melh, in 1931, was successful accomplished [1]. The first farms were deployed in the 1950s in the Bizert lagoon by an Italian farmer who imported spats of the Portuguese oyster breeding from France [1]. Until 1972, only C. angulata was cultured in the area, but after the collapse of the species populations in Europe due to an outbreak, the supply of natural spats ceased. Thus, ONP (Office National de Pêche) tried the breeding of the Japanese oyster Crassostrea gigas by

\footnotetext{
* Correspondence: salwadridi@yahoo.fr

'Institut Supérieur de Pêche et d'Aquaculture de Bizerte, ISPA -BP 15, ERRIMEL, 7080 Bizerte, Tunisia

Full list of author information is available at the end of the article
}

importing directly from Japan five $t$ of spats. This effort proved to be successful in time, due to a constant supply of spats from France [2].

Crassostrea gigas production increases from one $t$ in 2001 to eight $\mathrm{t}$ in 2003, and in 2010 it reached $10 \mathrm{t}$ representing $6.6 \%$ of the total shellfish production of Tunisia [3]. Tunisian production of C. gigas oyster is distributed exclusively on local markets and occupies the second position among the countries of North Africa, preceded by Morocco (i.e. $10 \mathrm{t}$ for a value of US $\$ 35,000$ and $284 \mathrm{t}$ for a value of US $\$ 538,000$ for Tunisia and Morocco in 2010, respectively). This production remains far from France, which is the first producer in Europe with $95,000 \mathrm{t}$ valued at US $\$ 428,905,000$ for 2010 [3].

The Bizert lagoon, covering an area of 15,000 ha, has been acknowledged for its aquaculture potential; this environment seems to be particularly suitable for oyster 
farming [4-7]. However, a gradual deterioration of environmental conditions in the Bizert lagoon has been detected since the 1960s, due to increased concentrations of nitrates and phosphates, probably related with population growth and industrial development in the area, which caused eutrophication phenomena [8]. This reality created the necessity of developing experimental oyster farms in maritime areas unaffected by pollution, such as the Port Princes in the Gulf of Tunis [9], to safeguard the products' quality and promote oyster industry in Tunisia.

Within this context the sexual cycle of Crassostrea gigas was compared between farmed populations in continental and marine areas. The obtained data will serve to evaluate the potential success of developing, in near future, oyster farms in marine areas of Tunis.

\section{Results}

Temperature, salinity and chlorophyll a

Temperature values followed similar temporal trends at both stations, varying from 12.2 to $28.7^{\circ} \mathrm{C}$ (average at $19.8 \pm 5.3^{\circ} \mathrm{C}$ ) at PP (see Methods), and from 10 to $30^{\circ} \mathrm{C}\left(20.7 \pm 6.3^{\circ} \mathrm{C}\right)$ at FMB (see Methods) (Figure 1). The average concentration of chlorophyll $a$ was lower at PP $\left(0.5 \pm 0.4 \mathrm{~g} \mathrm{l}^{-1}\right)$ than FMB $\left(0.8 \pm 0.6 \mathrm{~g} \mathrm{l}^{-1}\right)$; however similar temporal trends were observed (Figure 1) with minimum values recorded in December (0.15 $\mathrm{g} \mathrm{l}^{-1}$ at both stations) and maximum ones in April (1.75 $\mathrm{g} \mathrm{l}^{-1}$ and $2.4 \mathrm{~g} \mathrm{l}^{-1}$, for PP and FMB, respectively).

\section{Gonadal development stages}

The six stages of gonadal development previously described for the species were detected at both stations. Their distribution in PP and FMB oyster populations showed rather similar temporal trends (Figure 2A \& B), but with some differences related either to the month in which a stage started or ended, or to the percentage contribution of individuals per stage. The following pattern can be generally described for the studied oyster populations. Crassostrea gigas was at sexual resting (stage 0 , undifferentiated gonads) from September to March at both stations; early gametogenesis (stage I) started earlier in FMB (December) but ended later in PP (April) lasting about three to four months. Gametogenesis (stage II), characterized by the rising number of spermatogonia against the wall of acinus in
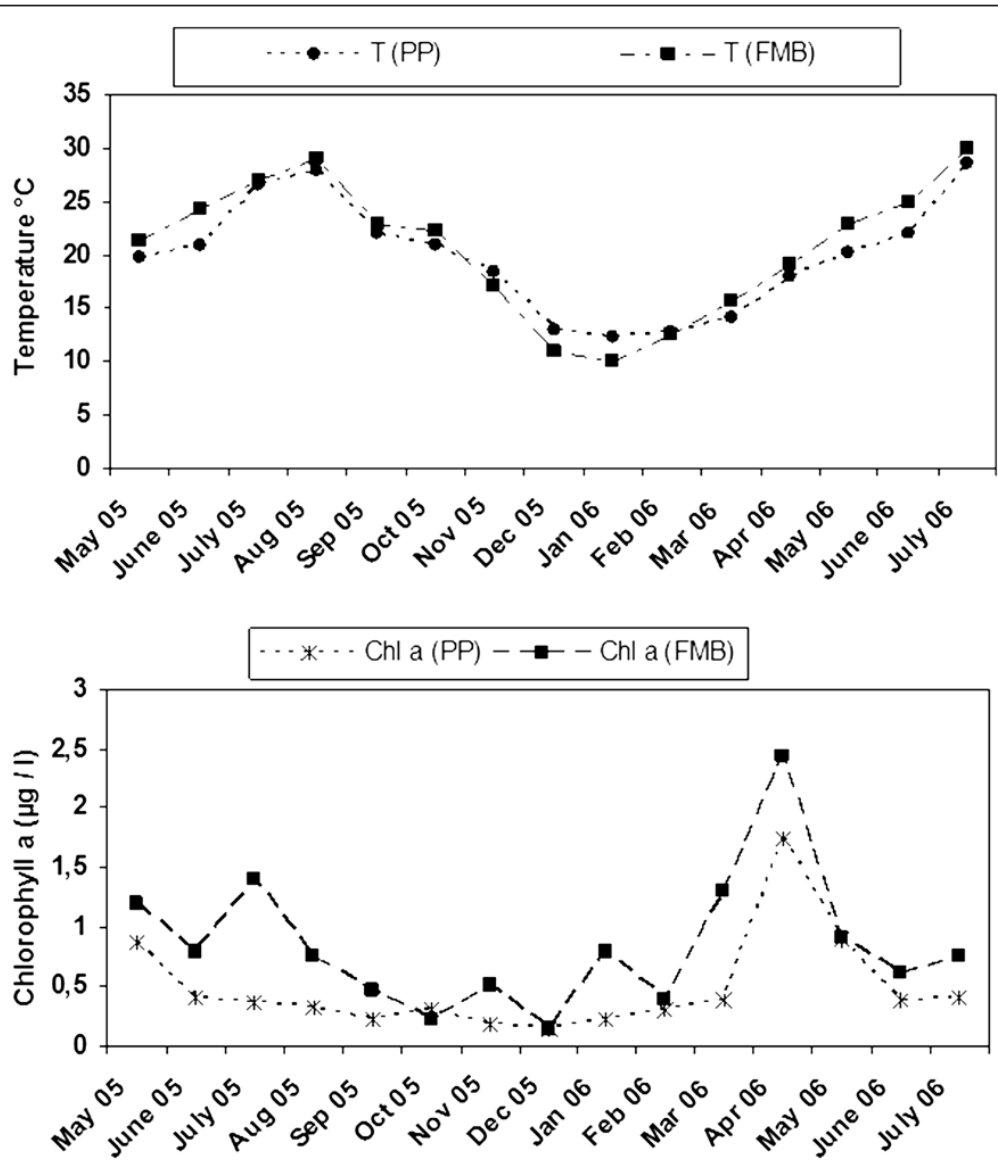

Figure 1 Monthly variations of temperature (T) and chlorophyll $a$ registered in Port aux Princes (PP) and in Ferme Marine de Bizerte (FMB) in Tunisia. 


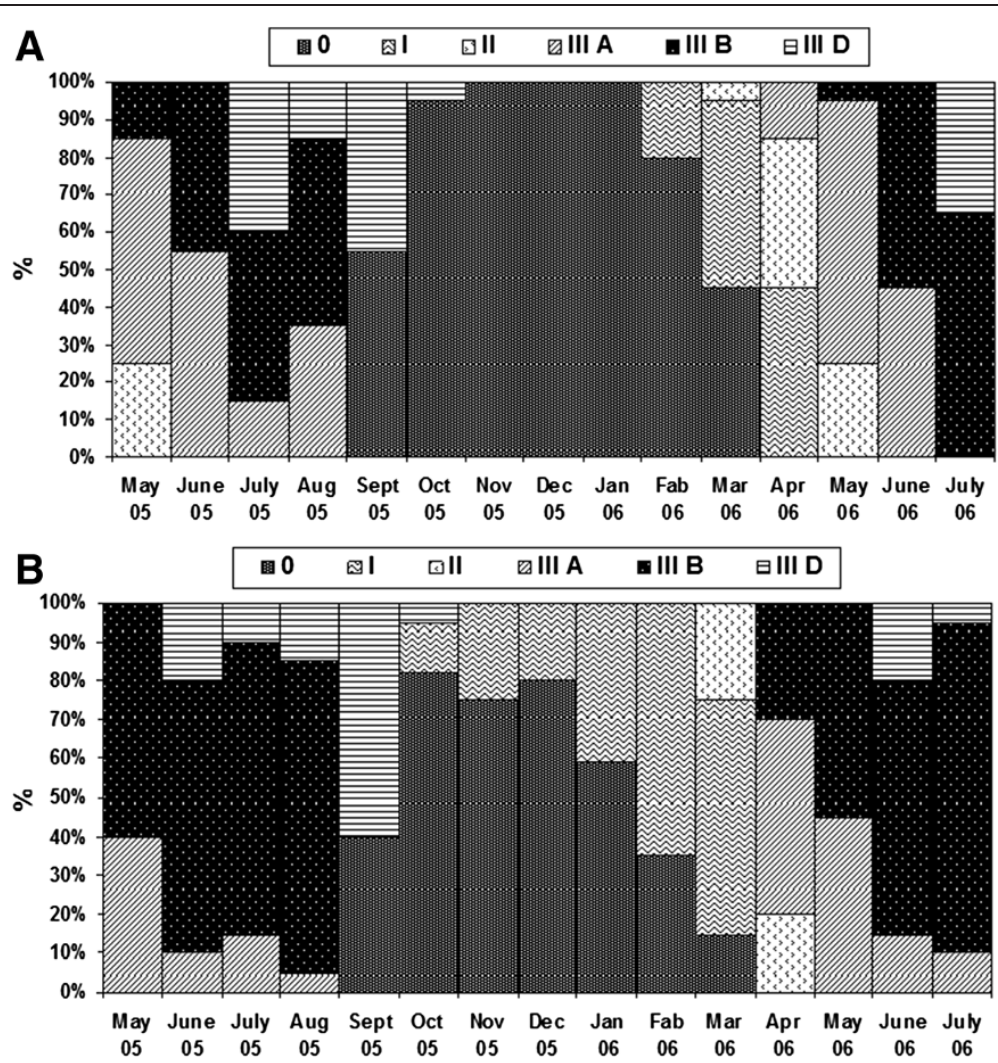

Figure 2 Variation of gonadic stages (\%) of Crassostrea gigas in (A) Port aux Princes (PP) and in (B) Ferme Marine de Bizerte (FMB). Stages: 0- Undifferentiated gonads, I- Early gametogenesis, II- Gametogenesis, IIIA- Intensive gametogenic activity, IIIB- Gonadal maturation and IIID- Spent gonads.

male and by the accumulation of vitells in the oocyte cytoplasm (previtellogenic oocytes) in females, expands from March to April (FMB) or May (PP). Intense gametogenic activity (stage IIIA) marked by the coexistence of spermatogonia, spermatocytes I and II and spermatides in the follicle of males, and of previtellogenic oocytes, adhering oocyte and peduncular oocytes (mature) in females, was observed from May 2005 to August 2005 and from April 2006 to June 2006, at both PP and FMB. The subsequent stage (stage IIIB) of gonadal maturation (homogenous aspect of gonads after the disappearance of spermatides running toward the center of the follicle in males, presence of numerous peduncular oocytes separated from the follicle lumen or going to be separated in females) was observed from April/May to July/August, whereas spent gonads (ruptured follicles, residual gametes, reappearance of connective tissues between the follicles and haemocytes invading gonadal tubules) were present from June (FMB) or July (PP) to September or October (FMB).

\section{Sex ratio and hermaphrodism in the studied C. gigas populations}

Sex ratio (males/females) ranged from 1.00 to 5.67 in PP and from 1.00 to 4.00 in FMB (Table 1), with an overall mean at 2.23 and 1.6, respectively. According to $x^{2}$ test results non-significant deviation from 1:1 ratio was detected to the overall population at both sites at $95 \%$ confidence level $\left(x^{2}=2.96\right.$ in PP and $\chi^{2}=3.3$ in FMB). Three cases of simultaneous hermaphroditism (one at PP and two at FMB), which is rare for $C$. gigas, were detected from the histological examination of the gonads (Figure 3 ).

\section{Spatio-temporal trends of oocyte diameter}

Mean oocyte diameter (MOD) showed significant temporal variability at both PP and FMB (Figure 4). In PP a gradual increase was recorded from May 2005 to June 2005; thereafter, maximum MOD values were detected until October 2005, where MOD presented a sudden drop as only individuals at the stage 0 were observed from November until January 2006. MOD started again to increase from March 2006 to reach again its maxima in July 2006. A rather similar pattern was detected in FMB; MOD showed increased values until September 2005, and dropped a month earlier in October 2005. In contrast to PP, MOD showed very low, but no-zero values, until January 2006, and then, started to increase to reach its maxima during the period May-July 2006. 
Table 1 Sex ratio of the studied C. gigas populations (20 oysters per month and per site)

\begin{tabular}{|c|c|c|c|c|c|c|}
\hline \multirow{2}{*}{ Months } & \multicolumn{3}{|c|}{ PP } & \multicolumn{3}{|c|}{ FMB } \\
\hline & Male & Female & Ratio males/females & Male & Female & Ratio males/females \\
\hline May 2005 & 12 & 8 & 1.5 & 12 & 8 & 1.50 \\
\hline June 2005 & 14 & 6 & 2.33 & 14 & 6 & 2.33 \\
\hline July 2005 & 15 & 5 & 3.00 & 16 & 4 & 4.00 \\
\hline August 2005 & 17 & 3 & 5.67 & 10 & 10 & 1.00 \\
\hline September 2005 & 10 & 10 & 1.00 & 12 & 8 & 1.50 \\
\hline October 2005 & - & - & - & 10 & 10 & 1.00 \\
\hline November 2005 & - & - & - & 12 & 8 & 1.50 \\
\hline December 2005 & - & - & - & 11 & 9 & 1.22 \\
\hline January 2006 & - & - & - & 6 & 14 & 0.43 \\
\hline February 2006 & 11 & 9 & 1.22 & 8 & 12 & 0.67 \\
\hline March 2006 & 16 & 4 & 4.00 & 7 & 13 & 0.54 \\
\hline April 2006 & 10 & 10 & 1.00 & 16 & 4 & 4.00 \\
\hline May 2006 & 12 & 8 & 1.50 & 15 & 5 & 3.00 \\
\hline June 2006 & 12 & 8 & 1.50 & 9 & 11 & 0.82 \\
\hline July 2006 & 13 & 7 & 1.86 & 7 & 13 & 0.54 \\
\hline
\end{tabular}

Two-way ANOVA detected non-significant differences in MOD between the two studied sites, whereas the relevant temporal differences were significant (Table 2). However, a significant interaction between sites and months was detected to allow further post-hoc comparisons.

A strong, positive and significant $(p<0.05)$ correlation between MOD and temperature was detected at both stations ( $r=0.83$ and $r=0.76$ for PP and FMB, respectively), whereas the relevant correlation with chlorophyll $a$ was weak $(r=0.1$ and $r=0.31$ for PP and FMB, respectively), though significant $(p<0.05)$.

Frequency distribution analysis of OD for each maturity stage (Figure 5) showed the gradual increase of oocyte size during sexual maturation. At PP during early gametogenesis most oocytes measured at about $6.5 \mu \mathrm{m}$ in diameter (February-April); during gametogenesis the bulk of oocytes was $30 \mu \mathrm{m}$ (March-May), whereas in maturity (May-August and April-July) and degeneration
(September) the mode further increased to $40 \mu \mathrm{m}$. At FMB, two modes were observed during early gametogenesis (December-March) at 5 and $10 \mu \mathrm{m}$ in diameter. During gametogenesis (March) oocyte diameter varied from 3.7 to $31 \mu \mathrm{m}$ with three modes at 6,10 and $21 \mu \mathrm{m}$, respectively; at this month, primary oocytes and previtellogenic oocytes coexisted. During maturation (May-August and April-July) and degeneration (after September), one mode at $40 \mu \mathrm{m}$ was observed.

\section{Spatio-temporal trends of the condition and gonadal condition indices}

CI and GCI showed increased values and diversified temporal pattern in FMB compared to PP sites (Figure 6 \& Figure 7). In FMB, maximum CI values were observed in May 2005 and 2006. The index decreased after May 2005 until August, and then, further decreased until October 2005, where it reaches its minima. Thereafter,

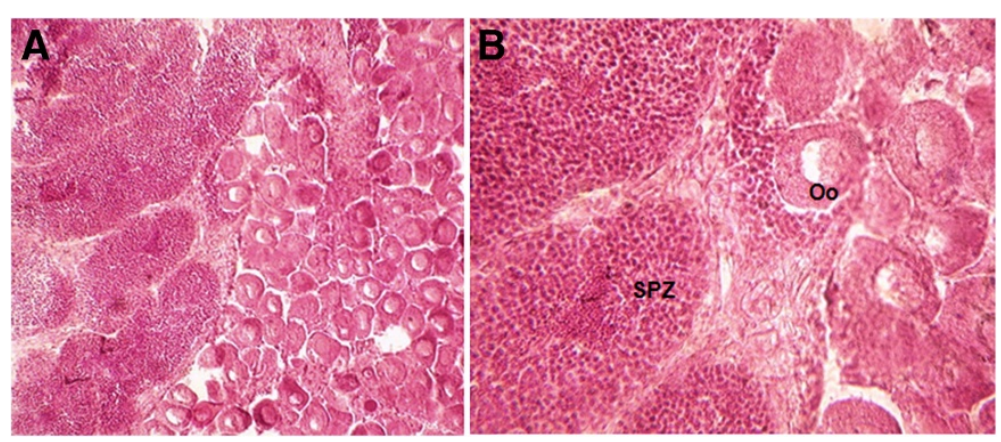

Figure 3 Simultaneous hermaphroditism in Crassostrea gigas. (A): Hermaphrodism ( $G=10 \times 10)$; (B): Hermaphrodism $(G=10 \times 40)$ $[\mathrm{SPZ}=$ Spermatozoides; Oo $=$ oocyte. 


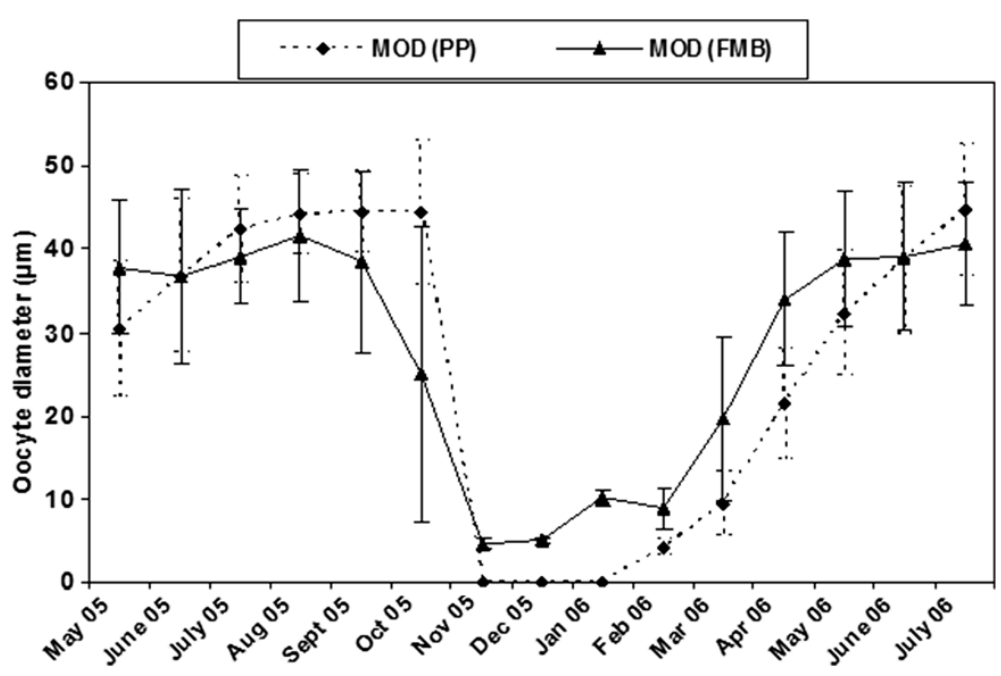

Figure 4 Average values of oocyte diameters in Crassostrea gigas at Port aux Princes (PP) and Ferme Marine de Bizerte (FMB).

a gradually increasing trend was observed until April 2006, getting again its maxima in May 2006, and followed by a decrease to its previous values in the next months (Figure 6). In PP the above pattern was modified. In 2005 maximum values were observed in June and minimum ones in July and October; after that month CI followed an increasing trend, reached its maxima in June 2006, and then dropped again in July 2006 (Figure 6).

Two-way ANOVA detected significant differences in CI at both spatial (i.e. between the two studied sites) and temporal scales (Table 2). However, a significant interaction between sites and months was detected to allow further post-hoc comparisons.

A very weak correlation between $\mathrm{CI}$ and temperature was detected at PP $(\mathrm{r}=-0.15, p<0.05)$, whereas the relevant correlation at FMB was non-significant. CI was also weakly correlated with chlorophyll $a$, at both stations $(r=0.37$ and $r=0.24$ for PP and FMB, respectively, $p<0.05$ ).

GCI index followed the same pattern with CI in both sampling stations, with some slight modifications only in the case of FMB population (Figure 7). Thus, in FMB maximum values were observed from March to May 2006, CI values were much higher in May 2006 compared to May 2005, and the decrease in June 2006 was much more pronounced.
Two-way ANOVA detected significant differences in GCI at both spatial (i.e. between the two studied sites) and temporal scales (Table 2). However, a significant interaction between sites and months was detected to allow further post-hoc comparisons, as the effect of these two factors seems to be overlapping.

At both stations very weak correlations between GCI and temperature $(\mathrm{r}=-0.15$ and $\mathrm{r}=-0.18$ for $\mathrm{PP}$ and FMB, respectively, $p<0.05$ ), and GCI and chlorophyll $a$ $(\mathrm{r}=0.30$ and $\mathrm{r}=0.41$ for PP and FMB, respectively, $p<0.05)$ were detected.

\section{Discussion}

The sexual cycle of C. gigas is characterized by an extended resting period, lasting from September to March. However, during this period a part of the population reached early gametogenesis at $\mathrm{FMB}$, in contrast to $\mathrm{PP}$ where all examined individuals were sexually inactive. Temperature is a widely acknowledged factor influencing oysters' reproduction; accelerated gametogenesis has been experimentally observed under increasing temperatures [10]. However, as slight differences in temperature were observed between the two sites, with lower values at FMB during winter, other factors may have been also involved. In FMB, increased chlorophyll $a$ values were recorded in

Table 2 Spatiotemporal effects on OD, $\mathrm{Cl}$ and $\mathrm{GCl}$ of the studied $\mathrm{C}$. gigas populations

\begin{tabular}{|c|c|c|c|c|c|c|c|c|c|c|}
\hline & \multirow[b]{2}{*}{ Df } & \multirow[b]{2}{*}{ Ms } & \multicolumn{2}{|c|}{ OD } & \multicolumn{3}{|c|}{$\mathrm{Cl}$} & \multicolumn{3}{|c|}{$\mathrm{GCl}$} \\
\hline & & & $F$ & $p$ & Ms & $F$ & $p$ & Ms & $F$ & $p$ \\
\hline Site & 1 & 307.94 & 2.28 & 0.13 & $2.28^{*}$ & $1046.14^{*}$ & $0.00^{*}$ & $0.28^{*}$ & $310.9^{*}$ & $0.00^{*}$ \\
\hline Months & 14 & 70.45 & 217.8 & $0.00^{*}$ & $5.60^{*}$ & $6.11^{*}$ & $0.00^{*}$ & $0.42^{*}$ & $7.12^{*}$ & $0.00^{*}$ \\
\hline Site $\times$ Months & 29 & 54.70 & 144.7 & $0.00^{*}$ & $1.17^{*}$ & $91.16^{*}$ & $0.00^{*}$ & $0.11^{*}$ & $43.89^{*}$ & $0.00^{*}$ \\
\hline
\end{tabular}

* denotes significant differences. 


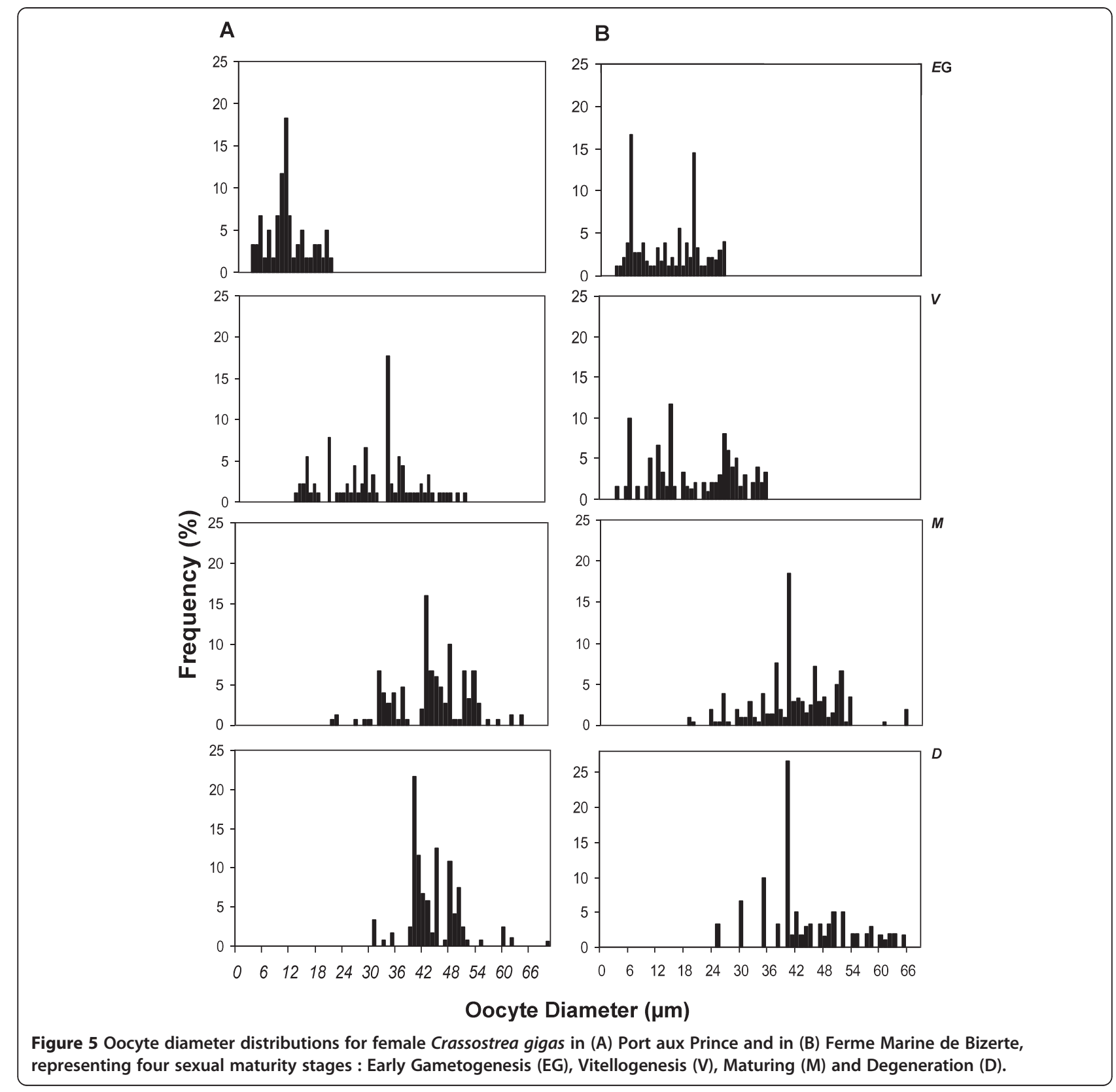

winter that could have activated the reproductive cycle of oysters, as food availability has been showed to trigger gametogenesis in C. gigas from the Atlantic French coast [11] and in Argopecten irradians from USA [12]. Early gametogenesis began in February at PP (water temperature: $12.7^{\circ} \mathrm{C}$ ) and in October at FMB (water temperature: $22.2^{\circ} \mathrm{C}$ ), four months in advance. The gametogenic activity of the species initiates at temperatures ranging from 8 to $18^{\circ} \mathrm{C}$ (see Table 3 summarizing existing information), this range amplifies up to $22^{\circ} \mathrm{C}$ according to our results.

Vitellogenesis started in March at both sites; however it was shorter and more intense in FMB, where increased temperature and chlorophyll $a$ values were recorded at that period. This conforms to previous data suggesting that the reproductive strategy of $C$. gigas is strongly affected by water temperature regulating the speed and thus, the length of gametogenesis, and also by nutrient content affecting the intensity of different gonadal stages [11]. Sexual maturity in C. gigas started in spring, when temperature and/or chlorophyll $a$ values further increased, being more intense and in advance in FMB. In this station, water temperature was higher during this period coinciding with the oyster's sexual maturity, as well as chlorophyll $a$ values, indicating the nutrient-rich environment of Bizert lagoon, compared to the open sea. It seems therefore that the warm water and the higher food availability of the Bizert lagoon 


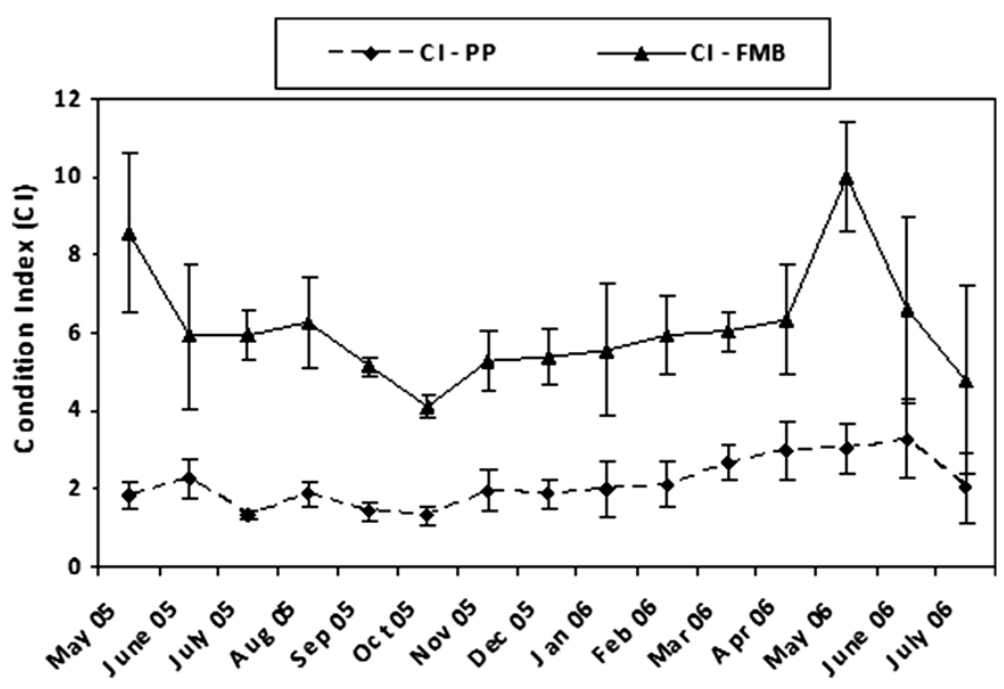

Figure 6 Variation of condition index (Cl) in Crassostrea gigas at Port aux Princes (PP) and a Ferme Marine de Bizerte (FMB).

favors the gametogenic cycle of C. gigas which is earlier and more intense than the gulf of Tunis (PP). Maturity reached at temperatures from $19-20^{\circ} \mathrm{C}$, which is well within the known temperature range for the species (see Table 1 summarizing existing information).

Comparing the gametogenic cycle of $C$. gigas with previous data from the Bizert lagoon [18] some differences came up. The reproductive pattern observed in 2002-2003 was rather similar with that currently observed at PP (discontinuous gametogenesis, initiation in February), but not with that from the same location (in 2005-2006, gametogenesis initiated in October and was continuous at FMB). Such spatiotemporal differences in the reproductive pattern of the species may be explained by relevant environmental differences. Indeed, the concentration of chlorophyll $a$ was almost twice as high in summer 2005 compared with 2002, probably inducing the recorded continuity of the gametogenic cycle. The duration of gametogenic cycle in C. gigas seems to follow a latitudinal gradient, controlled mainly by temperature [10], which may have a positive effect, either directly by affecting the metabolic rate of the species, or indirectly by enhancing food availability, as it has been showed for other bivalve species [20].

Temperature and food availability are among the most determining factor of gametogenesis in bivalves, which seems to be controlled by the spring phytoplankton blooms, and also, by phytoplankton concentration in

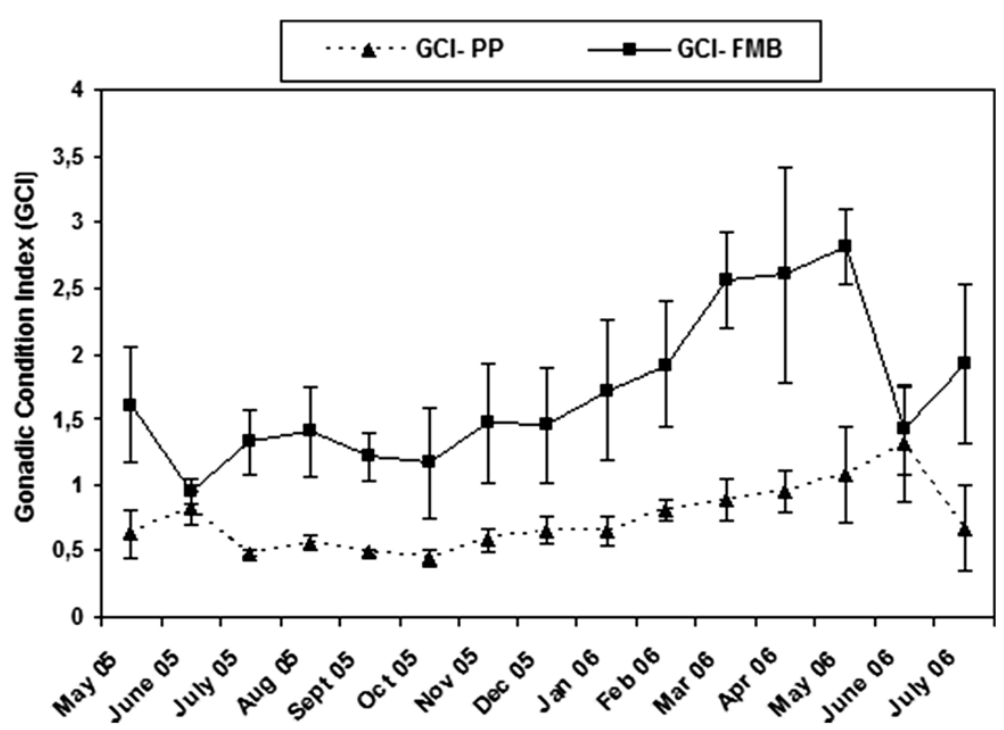

Figure 7 Variation of gonadosomatic index (GCl) in Crassostrea gigas at Port aux Princes (PP) and a Ferme Marine de Bizerte (FMB). 
Table 3 Temperature of gametogenesis initiation and gonads' maturity for C. gigas populations in different localities

\begin{tabular}{|c|c|c|c|}
\hline \multirow[t]{2}{*}{ Localities } & \multicolumn{2}{|c|}{ Temperature $\left({ }^{\circ} \mathrm{C}\right)$} & \multirow[t]{2}{*}{ References } \\
\hline & Initiation of gametogenesis & Gonads maturity & \\
\hline Woods Hole (USA) & $15-18^{\circ} \mathrm{C}$ & $18^{\circ} \mathrm{C}$ & [13] \\
\hline El Grove, Galicia (Spain) & $10^{\circ} \mathrm{C}$ & $16^{\circ} \mathrm{C}$ & [14] \\
\hline Onagawa Bay, Miyagi (Japan) & $8-10^{\circ} \mathrm{C}$ & $16-18^{\circ} \mathrm{C}$ & {$[15]$} \\
\hline La Tremblade (France) & $10-12^{\circ} \mathrm{C}$ & & [11] \\
\hline Malborough Sounds (New Zealand) & $12-13^{\circ} \mathrm{C}$ & $15-17^{\circ} \mathrm{C}$ & {$[16]$} \\
\hline Marennes Oléron Bay (France) & $8-12^{\circ} \mathrm{C}$ & $16-18^{\circ} \mathrm{C}$ & [17] \\
\hline Bizert lagoon (Tunisia) & $14-15^{\circ} \mathrm{C}$ & $16-20^{\circ} \mathrm{C}$ & [18] \\
\hline Sonora (Mexico) & $14^{\circ} \mathrm{C}$ & & [19] \\
\hline PP, Gulf of Tunis (Tunisia) & $12.7^{\circ} \mathrm{C}$ & $20.2^{\circ} \mathrm{C}$ & Present work \\
\hline FMB, Bizert lagoon (Tunisia) & $22.2^{\circ} \mathrm{C}$ & $19.2^{\circ} \mathrm{C}$ & Present work \\
\hline
\end{tabular}

winter, which determines the reserve storage [21-24]. Oysters under poor diet conditions, spent entirely their gametes and presents a short period of absorption, whereas under rich ones, they spent partially and follow a prolonged restoration period [11]. The absorption of gonads constitutes a "self-cleaning" process during which massive phagolysis of gametes takes place [11]; its output can be used either to cover basal metabolism [25], or to generate glycogen reserves which will be used to the next gametogenic cycle. The above may explain the observed differences considering the duration of the gonads absorption period between the studied oyster populations.

Both C. gigas populations studied showed an, overall, equal distribution of sexes, despite the predominance of males in several months, though these results must be cautionary interpreted as only 20 oysters per month and site have been examined. For the same species populations in Japan, sex ratio has been showed to be affected by the oyster length and age [26], with a predominance of males in both small, early stage and large, older oysters. These data have been interpreted as evidences of rhythmical hermaphroditism [26]. However, further research is required to assess relevant patterns in Mediterranean populations of C. gigas.

Oocyte diameter of $C$. gigas at sexual maturity varies around $34.9 \pm 9.8 \mu \mathrm{m}$ with a maximum of $61.4 \mu \mathrm{m}$ [27] or even $70 \mu \mathrm{m}$ [28], for French populations of the species. From the Sea of Japan even larger oocytes have been reported, reaching $80 \mu \mathrm{m}$ [29]; these voluminous oocytes have been attributed to the environmental conditions and the genetic structure of the studied population. In the present study average size of oocytes in maturity was larger in PP $(44.6 \pm 7.9 \mu \mathrm{m})$ than FMB $(40.7 \pm 7.4 \mu \mathrm{m})$ and it was strongly correlated with temperature. This result is in contradiction with previous data from other bivalve species reporting a positive relationship between food availability and oocyte diameter [30]. However, the ability of C. gigas populations to produce small oocytes when growing under plenty of food has been also demonstrated [31].

Oysters CI is directly related with the production of gametes, the increase of the somatic tissue, the shell growth and the secretion of mucus [32]. CI increased during the maturation phase and decreased when gametes are released and in the beginning of the sexual repose phase. During this latter phase, the species accumulate the necessary metabolites to start the next sexual cycle [33], and this gradual storage of organic matter may explain the subsequent increment of CI.

GCI results generally coincide with CI. GCI increased at the maturation phase and decreased when gonads are spent and during the sexual repose phase; these results are in accordance with the histological examination of C. gigas gonads. GCI temporal trends suggest the precocity and the faster gametogenic cycle of $C$. gigas in the Bizert lagoon compared with the Gulf of Tunis. However, as both indices presented weak correlation with temperature and chlorophyll $a$ other factors must be examined to explain the observed differences between the studied sites.

\section{Conclusions}

The results obtained allowed the comparison of the sexual cycle between oysters farmed in marine and lagoon environments. The oyster's gametogenic activity was successfully completed in both culture sites, following a clear seasonal pattern. Histological analysis, OD, CI and GCI data showed that the gametogenic cycle of C. gigas preceded in the lagoon environment, whereas the reproductive potential of the species was also increased in the latter habitat. These differences are probably related with relevant differences in thermal regime and trophic status of the two contrasting environments. Overall, the obtained results provide further evidence of the invasive character of C. gigas as the species is able to adapt in different 


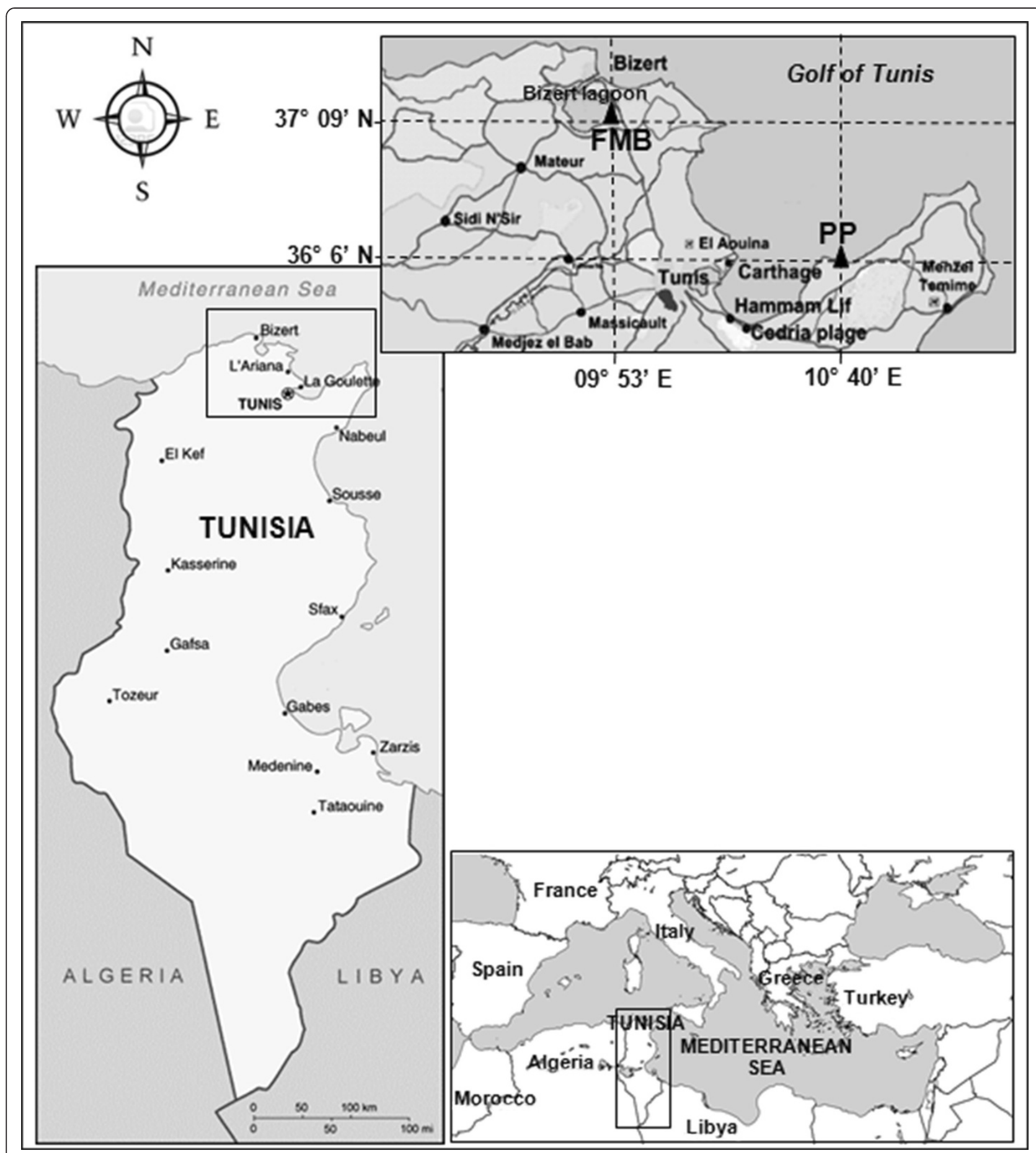

Figure 8 Sampling of C. gigas sites localisation in the Bizert lagoon (FMB) and the gulf of Tunis (PP).

environments. The development of oyster farms in marine localities of Tunis seems promising although more favorable conditions for C. gigas farming (i.e. increased chlorophyll $a$ concentrations) occurs in the Bizert lagoon, as suggested by CI and GCI results, which were by far higher in the oysters breeding in the lagoon.

\section{Methods}

\section{Study area and field sampling}

One oyster farming ground and an oyster purification site were selected as sampling sites: "Ferme Marine de Bizerte" (FMB), located in the southeast of the Bizert lagoon and "Port aux Princes" (PP), located in the eastern Gulf of 
Tunis, respectively (Figure 8). In both sites, oysters were placed in pockets suspended from rafts at $2 \mathrm{~m}$ depth.

Field samplings were completed from May 2005 to July 2006 on monthly basis at both sites and included the collection of $C$. gigas specimens (50 adult specimens per month and per site) measuring $8-10 \mathrm{~cm}$ in length (anterior-posterior distance measure) to assess the sexual cycle of the species, and the estimation of main physical and chemical parameters of the water column. Temperature was measured in situ at $1 \mathrm{~m}$ depth using an electronic thermometer (VWR, Vienna, Austria). Chlorophyll $a$ was estimated applying the fluorometric method by measuring the fluorescence before and after acidification of the methanolic pigment extract [34].

\section{Histological analysis and oocyte diameter}

In the laboratory, 20 of the collected C. gigas specimens, per month and per site, were dissected. Each visceral mass was fixed in the Bouin's solution and thereafter dehydrated in a series of increasing concentrations of ethanol. Dehydrated samples were cleared and embedded in paraffin following a standardized procedure [27]. Sections ( $6 \mu \mathrm{m}$ thick) were mounted on glass slides and stained with Groat's hematoxylin and eosin solution [35]. Each section was examined under light microscopy to determine sex and gonadal stage using the six-stages scale of gonadal development previously described for the species $[13,36]$.

Each month, five females from each station were randomly selected to determine Oocyte Diameter (OD). Approximately the diameter of 100 oocytes, with a visible nucleolus, were measured by female [15] using a microscope equipped with an ocular micrometer.

According to OD and histological characteristics of the gonad the sexual maturity of females was classified to the four-stages of development, i.e. Early Gametogenesis (EG), Vitellogenesis (V), Maturing (M) and Degeneration (D) previously described for C. gigas [27]. The size of degenerating oocytes, present after spawning, was not measured because they were torn or broken.

\section{Condition and gonadal condition indices}

Thirty of the collected C. gigas specimens, per month and per site, were used to calculate the Condition Index (CI) of the species, estimated as the percent ratio of flesh to shell dry weight [37]. The same specimens were used to estimate the Gonadal Condition Index (GCI), which was defined as the percent ratio of the visceral mass (gonad mixed with the hepatopancreas) to shell dry weight [38]. To assess dry weights, tissues and shells were dehydrated by maintained in oven at $60^{\circ} \mathrm{C}$ for $72 \mathrm{hrs}$ [22]; then, weights were measured using an electronic scale (precision $0.001 \mathrm{~g}$ ).

\section{Statistical analysis}

Two-way analysis of variance was used to test for temporal (among sampling months) and spatial (between sampling sites) effects on mean CI, GCI and OD values. Least Significant Differences test (LSD) was used for post hoc comparisons at 5\% significance level. Correlations between the measured abiotic variables (temperature and chlorophyll $a$ ) with OD, CI and GCI were also calculated. A $X^{2}$ test was used to assess whether oyster individuals were equally distributed among sexes. All statistical tests were performed using STATISTICA 10.0 (StatSoft, Tulsa, USA) software.

\section{Abbreviations \\ PP: Port aux princes; FMB: Ferme marine de Bizerte; GCl: Gonadal condition index; Cl: Condition index; OD: Oocyte diameter; MOD: Mean oocyte diameter; LSD: Least significant differences test.}

\section{Competing interests}

The authors declare that they have no competing interests.

\section{Authors' contributions}

SD: Conception and design of this work, conduction of the field and laboratory work, conduction of the analyses and interpretation of data, writing of the manuscript (as part of PhD thesis). MEC and MSR: Critical revision of the manuscript for important intellectual content and given final approval of the version to be published. All authors read and approved the final manuscript.

\section{Author details}

${ }^{1}$ Institut Supérieur de Pêche et d'Aquaculture de Bizerte, ISPA -BP 15 , ERRIMEL, 7080 Bizerte, Tunisia. ' Institut National Agronomique de Tunisie/, Département des Sciences de la, Production Animale et de la Pêche, Unité d'écosystèmes et ressources aquatiques, 43 Av. Charles Nicole, 1082 Tunis, Tunisia. ${ }^{3}$ Faculté des Sciences de Tunis/ Département de Biologie, Unité de Physiologie et d'Ecophysiologie des Organismes Aquatiques, Campus Universitaire, 2092, El Manar II, Tunis, Tunisia.

Received: 13 December 2013 Accepted: 17 April 2014

Published: 2 July 2014

\section{References}

1. Azzouz A: Etude des peuplements et des possibilités d'ostréiculture du Lac de Bizerte. Institut National Scientifique et Technique d'Océanographie et de Pêche: Salammbô; 1966.

2. Medhioub MN: Aperçu sur la conchyliculture en Tunisie point de situation et réflexions. Rev Inst Natl Agron Tunis 1993, 8:19-26.

3. FAO. [http://www.fao.org/figis/servlet/SQServlet?file=/work/FIGIS/prod/ webapps/figis/temp/hqp_2432021616643657610.xml\&outtype=html]

4. Gimazane JP, Medhioub N: Croissance de I'huître creuse Crassostrea gigas dans le lac de Bizerte à partir de naissains artificiels de petite taille. Bull Off Nat Des pêches de Tunisie 1979, 3:95-97.

5. Medhioub MN, Zaouali J: Captage de I'huître creuse Crassostrea gigas dans le lac d' Ichkeul. Bull Inst Nat Scient Tech Océanogr Pêche Salammbô 1988, 15:47-60.

6. Medhioub MN: La conchyliculture dans le lac de Monastir: élevage de la moule commune, de l'huître creuse et de la palourde méditerranéenne. Rapport et documents INSTOP/SALAMMBÔ 1990, 2:1-23.

7. Dridi $S$, Romdhane MS, El Cafsi M: Croissance et variations saisonnières de la composition en acides gras de l'huître Crassostrea gigas cultivée dans la lagune de Bizerte. Tunisie Belg J Zool 2008, 138:158-169.

8. Dellali M, Elbour M, Aïssa P: Evaluation de la pollution bactérienne dans la lagune de Bizerte : résultats préliminaires. J Rech Oceanogr 2001, 26:18-28.

9. Added A, Ben Mammou A, Abdeljaoued S, Essonni N, Fernex F: Caractérisation géochimique des sédiments de surface du golfe de Tunis. Bull Inst Nat Scient Tech Océanogr Pêche Salammbô 2003, 30:135-142. 
10. Chávez-Villalba J, Pommier J, Andriamiseza J, Pouvreau S, Barret J, Cochard J-C, Le Pennec M: Broodstock conditioning of the oyster Crassostrea gigas: origin and temperature effect. Aquaculture 2002, 214:115-130.

11. Chavez-Villalba JE, Mingant $C$, Cochard JC, Le Pennec M: Gamétogenèse chez I'huître Crassostrea gigas de l'Aber Benoît (Bretagne, France), à la limite nord de son aire de reproduction. Haliotis 2001, 30:1-12.

12. Barber BJ, Blake NJ: Growth and reproduction of the bay scallop, Argopecten irradians (Lamarck) at its southern distributional limit. J Exp Mar Biol Ecol 1983, 66:247-256.

13. Mann R: Some biochemical and physiological aspects of growth and gametogenesis in Crassostrea gigas and Ostrea edulis grown at sustained elevated temperatures. J Mar Biol Assoc UK 1979, 59:95-110.

14. Ruiz C, Abad M, Sedano LO, Garcia-Martin LO, Sanchez Lopez JL: Influence of seasonal environmental changes on the gamete production and biochemical composition of Crassostrea gigas (Thunberg) in suspended culture in El Grove, Galicia. Spain J Exp Mar Biol Ecol 1992, 155:249-262.

15. Li Q, Osada M, Mori K: Seasonal biochemical variations in Pacific oyster gonadal tissue during sexual maturation. Fisheries Sci 2000, 66:502-508.

16. Ren JS, Marsden ID, Ross AH, Schiel DS: Seasonal variation in the reproductive activity and biochemical composition of the Pacific oyster (Crassostrea gigas) from the Marlborough Sounds, New Zealand. New Zeal J Mar Fresh 2003, 37:171-182.

17. Fabioux C, Huvet A, Le Souchu P, Le Pennec M, Pouvreau S: Temperature and photoperiod drive Crassostrea gigas reproductive internal clock. Aquaculture 2005, 250:458-470.

18. Dridi S, Romdhane MS, Leitao A, El Cafsi M: Evidence for Crassostrea gigas reproduction in the Bizert lagoon. Tunisia J Biol Res-Thessalon 2006, 5:35-45.

19. Chávez-Villalba J, Villelas-Avila R, Cáceres-Martínez C: Reproduction, condition and mortality of the Pacific oyster Crassostrea gigas (Thunberg) in Sonora. México Aquaculture Res 2007, 38:268-278.

20. Laruelle F, Guillou J, Paulet YM: Reproductive pattern of the clams, Ruditapes decussatus and R. philippinarum on intertidal flats in Brittany. J. Mar. Biol. Assoc. U.K 1994, 74:351-366.

21. Mori K: Effects of artificial eutrophication on the metabolism of the Japanese oyster Crassostrea gigas. Mar Biol 1979, 53:361-369.

22. Deslous-Paoli J-M, Héral M, Berthome J-P, Razet D, Garnier J: Reproduction naturelle de Crassostrea gigas Thunberg dans le bassin de Marennes-Oléron en 1979 et 1981: aspects biochimiques et énergétiques. Rev Trav Inst Pêches Marit 1981, 45:319-327.

23. Maurer D, Borel M: Croissance, engraissement et cycle sexuel de Crassostrea gigas dans le bassin d'Arcachon: comparaison des huitres âgées de 1 et 2 ans. Haliotis 1986, 15:125-134.

24. Kang CK, Park MS, Lee PY, Choi WJ, Lee WC: Seasonal variations in condition, reproductive activity, and biochemical composition of the Pacific oyster, Crassostrea gigas (Thunberg), in suspended culture in two coastal bays of Korea. J Shellfish Res 2000, 19:771-778.

25. Beninger PG, Le Pennec M: Reproductive system. In Scallops: Biology, Ecology and Aquaculture. Edited by Shumway SE. Amsterdam: Elsevier Press; 1991:177-223.

26. Park JJ, Kim H, Kang SW, An CM, Lee S-H, Gye MC, Lee JS: Sex ratio and sex reversal in two-year-old class of oyster, Crassostrea gigas (Bivalvia: Ostreidae). Dev Reprod 2012, 16:385-388

27. Lango-Reynoso F, Chávez-Villalba J, Cochard JC, Le Pennec M: Oocyte size, a means to evaluate the gametogenic development of the Pacific oyster, Crassostrea gigas (Thunberg). Aquaculture 2000, 190:183-199.

28. Burlot G, Buthon L, Davaine Y, Didri H, Pabrou T, Rafini M, Valingot C, Synthèses Agricoles: Références Aquaculture. In Ecole Nationale d'Ingénieurs des travaux Agricoles de Bordeau, Département «Production Agricoles». ; 1998:229-256.

29. Yakovlev YM: Reproductive cycle of the pacific oyster (Crassostrea gigas Thunberg) in the Sea of Japan. Biol Morya 1977, 3:85-87.

30. Honkoop PJC, van der Meer J: Reproductive output of Macoma balthica populations in relation to winter-temperature and intertidal-height mediated changes of body mass. Mar Ecol Prog Ser 1997, 149:155-162.

31. Cardoso JFMF, Langlet D, Loff JF, Martins AR, Witte JIJ, Santos PT, van Der Veer HW: Spatial variability in growth and reproduction of the Pacific oyster Crassostrea gigas (Thunberg, 1793) along the west European coast. J Sea Res 2007, 57:303-315.

32. Héral M: La ostricultura francesca traditional. In Aquacultura. 2: El cultivo de moluscos equinodermos. Edited by Barnabé G. Barcelona: Omega; 1989:295-336.

33. Dridi S, Romdhane MS, El Cafsi M: Seasonal variation in weight and biochemical composition of the Pacific oyster, Crassostrea gigas in relation to the gametogenic cycle and environmental conditions of the Bizert lagoon, Tunisia. Aquaculture 2007, 263:238-248.

34. Aminot A, Chaussepied M: Manuel des analyses chimiques en milieu marin. CENEXO: Centrenational pour l'exploitation des océans; 1983.

35. Gabe M: Techniques histologiques. Paris: Masson et Cie; 1968

36. Lubet $P$ : Recherches sur le cycle sexuel et l'émission des gamètes chez les mytilidés et les Pectinidés (Mollusques Bivalves). Rev Trav Inst Pêches Marit 1959, 23:387-548.

37. Dridi S, Romdhane MS, El Cafsi M: Seasonal variation in weight and biochemical composition of the Pacific oyster Crassostrea gigas in relation to the gametogenic cycle and environmental conditions of the Bizert lagoon, Tunisia. Aquaculture (Elsevier) 2007, 263:238-248.

38. Paulet Y-M, Boucher J: Is reproduction mainly regulated by temperature or photoperiod in Pecten maximus? Invertebr Repr Dev 1991, 19:61-70.

doi:10.1186/2241-5793-21-13

Cite this article as: Dridi et al:: Gametogenic cycle of Crassostrea gigas in contrasting Mediterranean habitats: marine (Gulf of Tunis) and continental (Bizert lagoon) culture sites. Journal of Biological Research-Thessaloniki 2014 21:13.

\section{Submit your next manuscript to BioMed Central and take full advantage of:}

- Convenient online submission

- Thorough peer review

- No space constraints or color figure charges

- Immediate publication on acceptance

- Inclusion in PubMed, CAS, Scopus and Google Scholar

- Research which is freely available for redistribution 